\title{
LAYANAN BIMBINGAN KELOMPOK UNTUK MENINGKATKAN KEMAMPUAN KOMUNIKASI INTERPERSONAL
}

\author{
Oleh: \\ Rasni Sunarti Puspita Rahayu ${ }^{1)}$, Waode Suarni ${ }^{2)}$ \\ 1) 2) Jurusan Bimbingan dan Konseling \\ Fakultas Keguruan dan Ilmu Pendidikan, Universitas Halu Oleo \\ Email: ${ }^{1)}$ rasniani@gmail.com ${ }^{2)}$ waodesuarni@yahoo.com
}

\begin{abstract}
ABSTRAK
Penelitian ini bertujuan untuk mengetahui apakah layanan bimbingan kelompok dapat meningkatkan kemampuan komunikasi interpersonal siswa SMA Negeri 1 Maginti. Subjek dalam penelitian ini berjumlah 8 orang siswa yang memiliki kemampuan komunikasi interpersonal yang rendah. Jenis penelitian ini adalah penelitian pre eksperimen dengan desain one-grup pre-test and post-test. Metode pengumpulan data menggunakan angket komunikasi interpersonal. Hasil uji hipotesis dengan menggunakan Wilcoxon signed rank dengan taraf signifikan $\alpha=0,05$ diperoleh $\mathrm{P}_{\text {value }}=0,012 . \mathrm{P}_{\text {value }}<\alpha(0,012<0,05)$ dengan demikian $\mathrm{H}_{0}$ ditolak. Maka dapat disimpulkan layanan bimbingan kelompok dapat meningkatkan kemampuan komunikasi interpersonal siswa SMA Negeri 1 Maginti.
\end{abstract}

Kata Kunci: Komunikasi Interpersonal, Bimbingan Kelompok.

\section{GUIDANCE SERVICE GROUP TO IMPROVE INTERPERSONAL COMMUNICATION SKILLS}

\begin{abstract}
The Purpose of the research was to find out whether group counseling can improve students interpersonal communication skills at SMA Negeri 1 Maginti. The subjects of the research were 8 students who have experiencing low interpersonal communication skills. This type of research is pre-experimental research with one-group design pre-test and post-test. The data were collected via interpersonal communication skills questionnaires. The results of hypothesis testing using the Wilcoxon signed rank with a significant level of $\alpha=$ 0.05 obtained by $\mathrm{P}_{\text {value }}=0.012$. The value of $\mathrm{p}<\alpha(0.012<0.05)$ thus $\mathrm{H}_{0}$ is rejected. The results indicate that group counseling service can increase students isolation interpersonal communication skills in SMAN 1 Maginti.
\end{abstract}

Keywords: Interpersonal Communication, Group Guidance. 


\section{Pendahuluan}

Komunikasi merupakan salah satu hal yang sangat penting dalam proses kehidupan. Sebagian besar waktu yang dimiliki manusia digunakan untuk melakukan komunikasi. Kualitas dan kemampuan berkomunikasi menjadi ukuran sejauh mana seseorang dapat diterima atau tidak di lingkungan sosialnya. Melalui komunikasi, individu dapat memahami antar sesamanya dan mengetahui informasi mengenai lingkungan sekitarnya sehingga mampu mengambil keputusan dan tindakan sebagai respon informasi yang diberikan.

Rakhmat (2011: 4) mengemukakan bahwa komunikasi merupakan penyampaian energi dari alat-alat indera ke otak. Pada peristiwa penerimaan dan pengolahan informasi pada proses saling pengaruh di antara berbagai sistem dalam diri individu dan di antara individu. Komunikasi interpersonal atau disebut juga dengan komunikasi antar pribadi merupakan komunikasi yang dilakukan oleh individu untuk saling bertukar gagasan ataupun pemikiran kepada individu lainnya.

Komunikasi interpersonal tidak hanya tentang apa yang dikatakan dan apa yang diterima namun juga tentang bagaimana hal itu dikatakan, bagaimana bahasa tubuh yang digunakan dan apa ekspresi wajah yang diberikan. De Vito (2016: 30) mengemukakankomunikasi interpersonal adalah interaksi verbal dan nonverbal antara dua orang atau lebih yang saling tergantung satu sama lain. Komunikasi interpersonal merupakan bentuk komunikasi yang efektif dalam mengubah sikap, opini dan perilaku komunikan. Komunikasi interpersonal terjadi antara dua orang dengan bentuk percakapan face to face (tatap muka) dan adanya feed back (timbal balik) secara langsung atau seketika. Pada komunikasi interpersonal, komunikasi berlangsung secara mendalam karena komunikasi yang berlangsung bersifat dialogis dan para komunikan dapat berbicara sampai hal-hal yang bersifat pribadi. De Vito (2016: 184) mengemukakan ada lima karakteristik kemampuan komunikasi interpersonal yaitu (1) keterbukaan, (2) empati, (3) sikap mendukung, (4) sikap positif dan (5) kesetaraan.

Berdasarkan uraian sebelumnya, dapat dipahami bahwa komunikasi interpersonal merupakan kemampuan yang sangat penting yang harus dimiliki oleh seorang siswa. Untuk mencapai komunikasi interpersonal yang baik individu harus memiliki kemampuan dalam komunikasi interpersonal. Pada kenyataannya, di Sekolah Menengah Atas (SMA) Negeri 1 Maginti masih terdapat siswa yang memiliki kemampuan komunikasi interpersonal rendah. Berdasarkan data yang penulis peroleh pada wawancara dengan guru Bimbingan dan Konseling (BK) yaitu terdapat siswa yang tidak terbuka, tidak empati, tidak memiliki sikap mendukung dan tidak memiliki rasa kesetaraan.

Dampak yang muncul dari kegiatan komunikasi interpersonal yang rendah adalah sulitnya mengungkapkan perasaan siswa terhadap siswa lainnya ataupun terhadap guru mengenai permasalahan yang sedang dihadapinya, keengganan dalam melakukan interaksi komunikasi dalam kegiatan pembelajaran, munculnya sikap minder dan sering terjadi konflik antar siswa SMA Negeri 1 Maginti. Hal tersebut tidak dapat dibiarkan begitu saja karena dapat berpengaruh pada hasil belajar siswa. Oleh karena itu, diperlukan upaya-upaya dengan segera sebelum kondisi tersebut semakin buruk. Salah satu layanan yang dapat digunakan untuk meningkatkan komunikasi interpersonal siswa yaitu layanan bimbingan kelompok.

Layanan bimbingan kelompok merupakan upaya memfasilitasi siswa dalam suasana kelompok agar siswa dapat, mencegah serta memperbaiki dirinya dengan memanfaatkan dinamika kelompok, dengan demikian siswa yang bersangkutan dapat menjalani perkembangannya secara optimal. Kelompok yang dinamis adalah yang memiliki ciri-ciri dan tujuan bersama, saling membina hubungan yang dinamis, bersikap baikterhadap orang lain, memiliki kemampuan mandiri dan lain sebagainya.

Berdasarkan uraian pada latar belakang masalah tersebut maka penulis tertarik untuk melakukan penelitin dengan judul "Layanan Bimbingan Kelompok untuk Meningkatkan Kemampuan Komunikasi Interpersonal Siswa". Tujuan penelitian ini adalah mengetahui apakah layanan bimbingan kelompok dapat meningkatkan komunikasi kemampuan interpersonal siswa SMA Negeri 1 Maginti.

\section{Komunikasi Interpersonal}

Komunikasi interpersonal adalah komunikasi yang terjadi antara komunikator dan komunikan yang bersifat dialogis. Pengertian ini dapat dilihat dari pendapat De Vito (2016: 30) bahwa komunikasi interpersonal adalah interaksi verbal dan nonverbal antara dua orang atau lebih 
yang saling tergantung satu sama lain. Komunikasi interpersonal merupakan bentuk komunikasi yang efektif dalam mengubah sikap, opini dan perilaku komunikan. Komunikasi interpersonal terjadi antara dua orang dengan bentuk percakapan, face to face (tatap muka) dan adanya feedback (timbal balik) secara langsung atau seketika.

Di sisi lain, Wood (2013: 22) mendefinisikan komunikasi interpersonal adalah komunikasi yang memiliki karakteristik yaitu komunikasi terjadi dari satu orang ke orang lain, komunikasi berlangsung secara tatap muka dan isi dari komunikasi itu merefleksikan karakter pribadi dari tiap individu itu sebaik hubungan dan peran sosial mereka. Sementara itu, Aw (2011: 5) mengartikan komunikasi interpersonal sebagai proses penyampaian dan penerimaan pesan antara pengirim pesan (sender) dan penerima (receiver) baik secara langsung maupun tidak langsung. Komunikasi dikatakan terjadi secara langsung (primer) apabila pihak-pihak yang terlibat komunikasi dapat saling berbagi informasi tanpa melalui media sedangkan komunikasi tidak langsung (sekunder) dicirikan oleh adanya penggunaan media tertentu.

Berdasarkan pengertian tersebut, dapat dipahami bahwa komunikasi interpersonal mencakup aspek proses penyampaian pesan, pesan terjadi secara langsung dan tidak langsung, pesan menggunakan media, pesan tersebut memiliki tujuan dan komunikasi yang terjadi berlangsung efektif.

Karakteristik Kemampuan dalam Komunikasi Interpersonal

De Vito (2016: 184) menjelaskan bahwa kemampuan yang harus dimiliki dalam komunikasi interpersonal adalah sebagai berikut:

1. Keterbukaan. Keterbukaan dalam komunikasi interpersonal mengacu pada kesediaan untuk mengungkapkan diri untuk mengungkapkan informasi tentang diri sebagaimana mestinya. Keterbukaan juga termasuk kesediaan untuk mendengarkan secara terbuka dan bereaksi jujur terhadap pesan orang lain.

2. Empati. Merasakan apa yang orang lain rasakan dari sudut pandang orang itu. Empati adalah perasaan apa yang orang lain rasakan dari sudut pandang orang itu tanpa kehilangan identitas sendiri. Yang pertama dari empati, tentu saja, adalah memahami apa yang dipikirkan dan dirasakan orang lain.
3. Dukungan. Pesan yang mengekspresikan pemahaman daripada evaluasi. Dukungan dalam komunikasi adalah perilaku yang bersifat deskriptif. Pesan deskriptif menyatakan dalam istilah yang relatif obyektif apa yang dilihat atau apa yang dirasakan sebagai lawan dari pesan evaluatif, yang mengungkapkan pendapat dan penilaian diri. Pesan deskriptif dapat membuat orang lain merasa didukung, pesan menghakimi atau evaluatif, di sisi lain dapat menimbulkan pembelaan. (ini tidak berarti semua komunikasi evaluatif memenuhi respon defensif, tentu saja, misalnya, calon aktor yang ingin meningkatkan teknik sering menyambut baik evaluasi positif maupun negatif).

4. Positif. Suatu karakteristik keefektifan interpersonal yang melibatkan sikap positif dan penggunaan pesan-pesan positif yang mengekspresikan sikap-sikap ini (seperti dalam memuji orang lain) bersama dengan penerimaan dan persetujuan.

5. Kesetaraan. Sikap dan perilaku di mana setiap orang diperlakukan sama secara interpersonal. Dalam komunikasi interpersonal, istilah kesetaraan mengacu pada sikap atau pendekatan yang memperlakukan setiap orang sebagai kontributor penting dan penting untuk interaksi. Dalam situasi apa pun, tentu saja ada beberapa ketidaksetaraan, satu orang lebih tinggi dalam hierarki organisasi, lebih berpengetahuan, atau lebih interpersonal efektif.

Individu dikatakan memiliki perilaku komunikasi interpersonal yang efektif apabila ia memiliki kualitas komunikasi interpersonal tersebut dalam proses komunikasinya. Oleh karena itu, komunikasi interpersonal menjadi tidak efektif apabila individu-individu yang terlibat dalam proses komunikasi tidak memiliki dan menerapkan keterbukaan, empati, sikap mendukung, rasa positif dan kesetaraan. Berdasarkan paparan tersebut dapat dipahami bahwa komunikasi interpersonal bisa efektif bila ada keterbukaan, empati, sikap mendukung, rasa positif dan kesetaraan.

\section{Pentingnya Komunikasi Interpersonal}

Sebagai makhluk sosial, komunikasi interpersonal sangat penting bagi kebahagiaan hidup kita.Wood (2013:13) menunjukkan beberapa peranan yang disumbangkan oleh komunikasi interpersonal dalam rangka menciptakan kebahagiaan hidup manusia, yaitu sebagai berikut: 
1. Komunikasi interpersonal membantu perkembangan intelektual dan sosial kita,

2. Identitas dan jati diri kita terbentuk lewat komunikasi dengan orang lain,

3. Dalam rangka menguji realitas di sekeliling kita serta menguji kebenaran kesan-kesan dan pengertian yang kita miliki tentang di dunia di sekitar kita, kita perlu membandingkannya dengan kesan-kesan dan pengertian orang lain tentang realitas yang sama,

4. Kesehatan mental kita sebagian besar juga ditentukan oleh kualitas komunikasi atau hubungan kita dengan orang-orang lain, lebihlebih orang-orang yang merupakantokoh-tokoh signifikan dalam hidup kita.

Jadi, secara tidak langsung dengan berkomunikasi individu akan mengenali jati dirinya. Komunikasi juga memberikan berbagai informasi yang dapat membantu individu untuk belajar dan mengembangkan kemampuan intelektualnya. Kondisi mental seseorang juga dipengaruhi oleh kualitas komunikasinya. Oleh karena itu, sebagai makhluk sosial komunikasi interpersonal merupakan hal yang sangat penting bagi setiap individu.

\section{Layanan Bimbingan Kelompok}

Layanan bimbingan kelompok merupakan suatu cara memberikan bantuan (bimbingan) kepada individu (siswa) melalui kegiatan kelompok (Tohirin, 2007: 170). Senada dengan pendapat tersebut, Sukardi (2000: 48) menjelaskan bahwa layanan bimbingan kelompok dimaksudkan untuk memungkinkan siswa secara bersama-sama memperoleh berbagai bahan dari narasumber (terutama guru pembimbing) yang bermanfaat untuk kehidupan sehari-hari baik sebagai individu maupun sebagai pelajar, anggota keluarga dan masyarakat.

Selanjutnya, Prayitno dan Amti (2015: 307) menjelaskan bahwa istilah layanan bimbingan kelompok mengacu pada aktivitas-aktivitas kelompok yang berfokus kepada penyediaan informasi atau pengalaman lewat aktivitas kelompok yang terencana atau terorganisir. Isinya dapat meliputi informasi pendidikan, pekerjaan, pribadi atau sosial, bertujuan menyediakan bagi anggota-anggota kelompok informasi akurat yang dapat membantu mereka membuat perencanaan dan keputusan hidup yang lebih tepat sedangkan Wardati dan Jauhar (2011: 105) menjelaskan bahwa layanan bimbingan kelompok adalah usaha yang dilakukan untuk mencegah berkembangnya masalah atau kesulitan pada diri konseli.

Dari beberapa pengertian layanan bimbingan kelompok tersebut, dapat dipahami bahwa bimbingan kelompok adalah suatu kegiatan kelompok yang dilakukan oleh sekelompok orang dengan memanfaatkan dinamika kelompok yaitu adanya interaksi saling mengeluarkan pendapat, memberikan tanggapan, saran dan sebagainya, dimana pemimpin kelompok menyediakan informasi-informasi yang bermanfaat agar dapat membantu individu mencapai perkembangan yang optimal.

\section{Tujuan Layanan Bimbingan Kelompok}

Secara umum layanan bimbingan kelompok bertujuan untuk pengembangan kemampuan bersosialisasi, khususnya kemampuan berkomunikasi peserta layanan (siswa). Secara lebih khusus, layanan bimbingan kelompok bertujuan untuk mendorong pengembangan perasaan, pikiran persepsi, wawasan dan sikap yang menunjang perwujudan tingkah laku yang lebih efektif, yakni peningkatan kemampuan berkomunikasi baik verbal maupun nonverbal para siswa (Tohirin, 2007: 172).

Selanjutnya, Prayitno (2012:

menjelaskan tujuan layanan bimbingan kelompok terdiri atas dua bagian yaitu tujuan umum dan tujuan khusus sebagai berikut:

1. Tujuan umum layanan bimbingan kelompok adalah berkembangnya kemampuan sosialisasi siswa, khususnya kemampuan komunikasi anggota kelompok. Melalui layanan bimbingan kelompok, hal-hal yang mengganggu atau menghimpit perasaan dapat diungkapkan, dilonggarkan dan diringankan melalui berbagai cara, pikiran yang suntuk, buntu atau beku dicairkan melalui berbagai masukan dan tanggapan baru, persepsi dan wawasan yag menyimpang atau sempit, diluruskan dan diperluas melalui pencairan pikiran, penyadaran dan penjelasan, sikap yang tidak objektif, terkungkung dan tidak terkendali serta tidak efektif digugat dan didobrak, kalau perlu diganti dengan yang baru yang lebih efektif.

2. Tujuan khusus layanan bimbingan kelompok adalah untuk membahas topik-topik tertentu yang mengandung permasalahan aktual (hangat) dan menjadi perhatian semua anggota kelompok. Melalui dinamika kelompok yang intensif, pembahasan topik-topik itu mendorong pengembangan perasaan, pikiran, persepsi, 
wawasan dan sikap yang menunjang diwujudkannya tingkah laku yang lebih efektif dan bertanggung jawab, dalam hal ini kemampuan berkomunikasi verbal maupun non verbal ditingkatkan.

\section{Dinamika Kelompok}

Winkel dan Hastuti (2006: 547) mengatakan bahwa dinamika kelompok adalah pengetahuan yang menggambarkan berbagai kekuatan yang menunjukkan perilaku anggota dan perilaku kelompok yang menyebabkan terjadinya gerak perubahan dalam kelompok untuk mencapai tujuan bersama yang telah ditetapkan. Dinamika kelompok merupakan sinergi dari semua faktor yang ada dalam suatu kelompok, artinya merupakan pengarahan secara serentak semua faktor yang dapat digerakan dalam kelompok itu. Selanjutnya, Winkel dan Hastuti (2006: 547) menjelaskan dinamika kelompok mengarahkan anggota kelompok untuk melakukan hubungan interpersonal satu sama lain. Hubungan interpersonal ini merupakan wahana bagi para anggota untuk saling berbagi pengetahuan, pengalaman dan bahkan perasaan satu sama lain sehingga memungkinkan terjadinya proses belajar didalam kelompok yang kohesif.

Prayitno (2002: 32) menguraikan peranan yang hendaknya dimainkan oleh anggota kelompok agar dinamika kelompok itu benar-benar seperti yang diharapkan adalah:

1. Membantu terbinanya suasana keakraban dalam hubungan antar anggota kelompok.

2. Mencurahkan segenap perasaan dalam melibatkan diri dalam kegiatan kelompok.

3. Berusaha agar yang dilaksanakannya itu membantu tercapainya tujuan bersama.

4. Membantu tersusunnya aturan kelompok dan berusaha mematuhinya dengan baik.

5. Benar-benar berusaha untuk secara aktif ikut serta dalam seluruh kegiatan kelompok.

6. Mampu berkomunikasi secara terbuka.

7. Berusaha membantu anggota lain.

8. Memberi kesempatan kepada anggota lain untuk juga menjalankan perannya.

9. Menyadari pentingya kegiatan kelompok itu.

Dari penjelasan di atas, dapat disimpulkan bahwa bimbingan kelompok memanfaatkan dinamika kelompok sebagai wahana dalam membimbing anggota kelompok untuk mencapai tujuan. Dinamika kelompok adalah kekuatan di dalam kelompok yang menentukan perilaku kelompok dan anggotanya agar tercapai tujuan kelompok, dinamika kelompok mengarahkan anggota kelompok menjalin hubungan interpersonal sehingga proses bimbingan kelompok diharapkan dapat berjalan dengan lancar sesuai dengan prosedur dan sistematika yang baik.

Tahapan Layanan Bimbingan Kelompok

Keberhasilan dalam melakukan pembentukan kelompok akan sangat menentukan efektivitas bimbingan dan konseling sehingga konselor perlu melakukan pembentukan kelompok dengan langkah-langkah dan tahapan yang akurat, sistematis dan berkesinambungan. Prayitno (2013: 170-171) menjelaskan bahwa penyelenggaraan layanan bimbingan kelompok dilakukan melalui lima tahap kegiatan.

1. Tahap pembentukan, yaitu tahapan untuk membentuk kerumunan sejumlah individu menjadi satu kelompok yang siap mengembangkan dinamika kelompok dalam mencapai tujuan bersama. Kegiatan-kegiatan yang harus dilakukan pada tahap pembentukan adalah sebagai berikut:

a. Mengungkapkan pengertian dan tujuan kegiatan bimbingan kelompok dalam rangka pelayanan bimbingan kelompok.

b. Menjelaskan cara-cara dan asas-asas kegiatan bimbingan kelompok.

c. Saling memperkenalkan dan mengungkapkan diri.

d. Permainan penghangatan/ pengakraban.

2. Tahap peralihan, yaitu tahapan untuk mengalihkan kegiatan awal kelompok pada kegiatan berikutnya yang lebih terarah pada pencapaian tujuan kelompok. Kegiatan-kegiatan yang harus dilakukan pada tahap peralihan adalah sebagai berikut:

a. Menjelaskan kegiatan yang akan ditempuh pada tahap berikutnya.

b. Menawarkan sambil mengamati apakah para anggota sudah siap menjalani kegiatan pada tahap selanjutnya (tahap ketiga).

c. Membahas suasana yang terjadi.

d. Meningkatkan kemampuan keikutsertaan anggota. Kalau perlu kembali ke beberapa aspek tahap pertama (tahap pembentukan).

3. Tahap kegiatan, tahap ini merupakan "kegiatan inti" untuk membahas topik-topik tertentu. Dalam tahapan ini, kegiatan kelompok dibagi menjadi dua yakni pembahasan topik dan pembahasan tugas. Kegiatan-kegiatan yang 
harus dilakukan pada tahap pembahasan topik adalah sebagai berikut:
a. Masing-masing anggota secara bebas mengemukakan pendapat terhadap topik pembahasan.
b. Menetapkan topik yang akan dibahas terlebih dahulu.
c. Anggota membahas topik secara mendalam dan tuntas.
d. Kegiatan selingan.

Selanjutnya, kegiatan-kegiatan yang harus dilakukan pada tahap pembahasan tugas adalah sebagai berikut:

a. Pemimpin kelompok mengemukakan suatu topik untuk dibahas oleh anggota kelompok.

b. Tanya jawab antara anggota dan pemimpin kelompok tentang hal-hal yang belum jelas yang menyangkut topik yang dikemukakan pemimpin kelompok.

c. Anggota kelompok membahas topik tersebut secara mendalam dan tuntas.

d. Kegiatan selingan.

4. Tahap penyimpulan, tahap ini merupakan tahap kegiatan untuk melihat kembali apa yang sudah dilakukan dan dicapai oleh kelompok. Anggota kelompok diminta melakukan refleksi berkenaan dengan kegiatan pembahasan yang baru saja mereka ikuti. Kegiatan-kegiatan yang harus dilakukan pada tahap penyimpulan adalah sebagai berikut:

a. Pemimpin kelompok meminta anggota kelompok mengemukakan kesan dan hasilhasil kegiatan.

b. Anggota kelompok mengemukakan pesan dan harapan.

5. Tahap penutupan, yaitu merupakan tahap akhir dari seluruh kegiatan. Kelompok merencanakan kegiatan bimbingan kelompok selanjutnya dan menyampaikan salam hangat perpisahan. Kegiatan-kegiatan yang harus dilakukan pada tahap penutupan adalah sebagai berikut.

a. Kelompok membahas kegiatan lanjutan.

b. Kelompok mengakhiri kegiatan bimbingan kelompok.

\section{Metode Penelitian}

Penelitian ini dilaksanakan di SMA Negeri 1 Maginti yang beralamat di jalan $\mathrm{H}$. Tombong Pajala Kecamatan Maginti Kabupaten Muna Barat. Penelitian ini dilaksanakan selama 3 bulan yakni dimulai dari bulan Januari sampai Bulan Maret 2018.
Penelitian ini merupakan jenis penelitian kuantitatif dengan metode pra eksperimen. Pra eksperimen merupakan susunan desain penelitian yang dilakukan dengan jalan memberikan perlakuan kepada subjek tanpa adanya kelompok kontrol (Latipun, 2002:68). Bentuk desain pra eksperimen yang digunakan adalah one group pre test and post test design.Menurut Gall,Gall \& Borg (dalam Setyosari, 2013: 281) desain penelitian one group pre test-post test meliputi tiga langkah, yaitu: a) pelaksanaan pre test untuk mengukur variabel terikat, b) pelaksanaan perlakuan atau eksperimen dan c) pelaksanaan post test untuk mengukur hasil atau dampak terhadap variabel terikat.

Subjek dalam penelitian ini adalah siswa di SMA Negeri 1 Maginti berjumlah 8 orang siswa yang memiliki keterampilan komunitas interpersonal yang rendah.

Teknik pengumpulan data dan instrumen penelitian yang digunakan dalam penelitian ini adalah angket kemampuan komunikasi interpersonal. Teknik analisis data dalam penelitian ini menggunakan analisis deskriptif dan analisis statistik inferensial. Teknik analisis deskriptif digunakan untuk mengetahui gambaran perilaku siswa terisolir maka skor jawaban akan dikonversikan ke dalam 4 kategori penilaian yang terdiri dari: sangat tinggi, tinggi, rendah, sangat rendah.

Analisis statistik inferensial digunakan untuk menguji hipotesis penelitian. Pengujian hipotesis dilakukan dengan menggunakan statistika non parametik yaitu dengan uji wilcoxon signed rank. Adapun rumusan bentuk hipotesis adalah: jika $\mathrm{P}_{\text {value }}>\alpha$ maka $\mathrm{H}_{0}$ diterima, sedangkan jika $\mathrm{P}_{\text {value }}>\alpha$ maka $\mathrm{H}_{\mathrm{a}}$ yang diterima.

Keterangan:

Jika $\quad \mathrm{H}_{0} \quad$ : Bimbingan kelompok tidak diterima dapat meningkatkan kemampuan komunikasi interpersonal siswa.

Jika $\quad \mathrm{H}_{\mathrm{a}}$ : Bimbingan kelompok dapat diterima meningkatkan kemampuan komunikasi interpersonal siswa. 


\section{Hasil Penelitian dan Pembahasan \\ Hasil Penelitian}

Analisis Deskriptif Persentase

Gambaran Kemampuan Komunikasi Interpersonal

Siswa Sebelum Diberi Perlakuan (Pre Test).

Gambaran kemampuan komunikasi interpersonal siswa kelas XI di SMA Negeri 1 Maginti sebelum diberikan perlakuan (pre test) dapat diketahui berdasarkan hasil pengisian angket komunikasi interpersonal siswa yang disebar pada 80 orang siswa. Siswa yang memiliki skor kemampuan komunikasi interpersonal terendah diberikan perlakuan berupa layanan bimbingan kelompok. Untuk mengetahui gambaran komunikasi interpersonal siswa sebelum diberikan perlakuan maka skor yang diperoleh subjek penelitian terlebih dahulu dikonversi kedalam kategori penilaian dengan menggunakan analisis deskriptif sebagaimana yang disajikan pada tabel berikut:

\section{Tabel 1}

Skor Pre Test Siswa Sebelum Diberikan Layanan Bimbingan Kelompok.

\begin{tabular}{|c|c|c|c|}
\hline No & Nama & Skor & Kategori \\
\hline 1 & AN & 216 & Rendah \\
\hline 2 & IY & 225 & Rendah \\
\hline 3 & AF & 223 & Rendah \\
\hline 4 & AR & 209 & Rendah \\
\hline 5 & ALW & 224 & Rendah \\
\hline 6 & REM & 225 & Rendah \\
\hline 7 & SAM & 224 & Rendah \\
\hline 8 & NR & 224 & Rendah \\
\hline \multicolumn{2}{|c|}{ Rata-rata } & $\mathbf{2 2 1}$ & Rendah \\
\hline
\end{tabular}

Berdasarkan data pada tabel tersebut, skor komunikasi interpersonal siswa kelas XI di SMA Negeri 1 Maginti sebelum diberikan perlakuan termasuk dalam kategori rendah. Hal ini dapat dilihat dari rata-rata komunikasi interpersonal siswa yang hanya mencapai skor 121 dari 8 orang subjek penelitian.

Gambaran kemampuan komunikasi interpersonal Siswa Setelah Diberikan Perlakuan (Post Test)

Gambaran kemampuan komunikasi interpersonal siswa kelas XI SMA Negeri 1 Maginti setelah diberikan perlakuan berupa layanan bimbinan kelompok dapat diketahui berdasarkan hasil analisis angket komunikasi interpersonal siswa, sebagaimana yang tertera pada tabel berikut:

Tabel 2

Skor Post Test Siswa Setelah Diberikan Layanan Bimbingan Kelompok.

\begin{tabular}{|c|c|c|c|}
\hline No & Nama & Skor & Kategori \\
\hline 1 & AN & 268 & Tinggi \\
\hline 2 & IY & 266 & Tinggi \\
\hline 3 & $\mathrm{AF}$ & 304 & Sangat \\
\hline 4 & IR & 284 & Tinggi \\
\hline 5 & ALW & 238 & Tinggi \\
\hline 6 & REM & 255 & Tinggi \\
\hline 7 & SAM & 254 & Tinggi \\
\hline 8 & $\mathrm{NR}$ & 246 & Tinggi \\
\hline \multicolumn{2}{|c|}{ Rata-rata } & 264 & Tinggi \\
\hline
\end{tabular}

Berdasarkan data pada tabel tersebut, skor kemampuan komunikasi interpersonal siswa setelah diberikan perlakuan (post test) mengalami perubahan dari kategori rendah menjadi kategori tinggi. Hal ini dapat dilihat dari rata-rata yang diperoleh skor sebesar 264 dari 8orang subjek penelitian.

Gambaran kemampuan komunikasi interpersonal Siswa Sebelum \& Sesudah Pemberian Layanan Bimbingan kelompok

Berdasarkan hasil analisis data, maka dapat diperoleh gambaran kemampuan komunikasi interpersonal siswa Kelas XISMA Negeri 1 Maginti sebelum dan sesudah diberikan layanan. Adapun hasil analisis data tersebut dapat dilihat pada tabel berikut:

Tabel 3

Perbandingan Skor Pre Test dan Post Test Siswa

\begin{tabular}{|c|c|c|c|c|}
\hline \multirow{2}{*}{ No } & \multirow{2}{*}{ Nama } & \multicolumn{2}{|c|}{ Skor } & \multirow{2}{*}{$\%$ Peningkatan } \\
\cline { 3 - 4 } & & Pre test & Post test & \\
\hline 1 & AN & 216 & 268 & $14,44 \%$ \\
\hline 2 & IY & 225 & 266 & $11,38 \%$ \\
\hline 3 & AF & 223 & 304 & $22,5 \%$ \\
\hline 4 & IR & 209 & 284 & $20,83 \%$ \\
\hline 5 & ALW & 224 & 238 & $3,88 \%$ \\
\hline 6 & REM & 225 & 255 & $8,61 \%$ \\
\hline 7 & SAM & 224 & 254 & $8.33 \%$ \\
\hline 8 & NR & 224 & 246 & $6,11 \%$ \\
\hline \multicolumn{2}{|c|}{ Rata-rata } & $\mathbf{2 2 1}$ & $\mathbf{2 6 4}$ & $\mathbf{1 1 , 9 4 \%}$ \\
\hline
\end{tabular}

Dari tabel tersebut diketahui bahwa sebelum diberi perlakuan (pre test) tingkat kemampuan komunikasi interpersonal siswa masuk dalam kategori rendah dengan rata-rata mencapai skor 221 sedangkan setelah diberikan perlakuan (post 
test) tingkat kemampuan komunikasi interpersonal siswa berada pada kategori tinggi dengan skor ratarata sebesar 264. Hal tersebut menunjukkan bahwa tingkat kemampuan komunikasi interpersonal siswa kelas XIMA Negeri 1 Maginti mengalami peningkatan sebesar $11,94 \%$ setelah diberikan perlakuan berupa layanan bimbingan kelompok.

\section{Analisis Statistik Inferensial}

Analisis data untuk mengetahui apakah pemberian layanan bimbingan kelompok dapat meningkatkan kemampuan komunikasi interpersonal siswa kelas XI SMA Negeri 1 Maginti dilakukan dalam non-parametrik menggunakan uji wilcoxon signed rank. Uji wilcoxon signed rank dapat didasarkan pada sampel kecil $(\mathrm{n} \leq 25)$ dengan taraf signifikan 0.05 (Sugiyono, 2010). Uji Wilcoxon signed rank dengan menggunakan SPSS versi 16.0.

Berdasarkan hasil uji wilcoxon signed rank pada taraf signifikansi $\alpha=0,05$ diperoleh $\mathrm{P}_{\text {value }}=$ 0,012. $\mathrm{P}_{\text {value }}<\alpha(0,012<0,05)$ dengan demikian $\mathrm{H}_{0}$ ditolak yang artinya bahwa terdapat peningkatan kemampuan komunikasi interpersonal siswa sesudah diberikan layanan bimbingan kelompok. Hal ini berarti layanan bimbingan kelompok dapat meningkatkan kemampuan komunikasi interpersonal siswa.

\section{Pembahasan}

Sebelum diberi perlakuan (pre test) tingkat kemampuan komunikasi interpersonal siswa masuk dalam kategori rendah dengan rata-rata hanya mencapai skor 221. Setelah diberikan layanan bimbingan kelompok, secara deskriptif menunjukkan adanya peningkatan dengan rata-rata mencapai skor 264. Layanan bimbingan kelompok dapat meningkatkan kemampuan komunikasi interpersonal siswa, sebagaimana yang diperoleh hasil dalam penelitian ini bahwa tingkat kemampuan komunikasi interpersonal siswa kelas XI SMA Negeri 1 Maginti mengalami peningkatan sebesar $11,94 \%$ setelah diberikan perlakuan.

Hasil pengolahan data secara keseluruhan, karakteristik kemampuan komunikasi interpersonal mengalami peningkatan. Karakteristik keterbukaan pengalami peningkatan sebesar $18,33 \%$. De Vito (2011: 64) mengemukakan bahwa keterbukaan diri adalah jenis komunikasi dimana seseorang mengukapkan informasi tentang diri sendiri yang biasanya disembunyikan. Keterbukaan merupakan kemauan menaggapi dengan senang hati informasi yang diterima di dalam menghadapi hubungan interpersonal. Keterbukaan ditandai oleh terbuka kepada oarang yang diajak berinteraksi dan mendengarkan dengan penuh perhatian. Oleh karena itu keterbukaan memegang peranan penting dalam kehidupan sehari-hari. Dengan keterbukaan seseorang dapat menyampaikan informasi tentang dirinya, mengokohkan keakraban dan membangun kepercayaan.

Hasil penelitian ini memperkuat hasil penelitian yang dilakukan oleh Erlangga (2017) yang menunjukan bahwa layanan bimbingan kelompok dapat meningkatkan keterampilan berkomunikasi siswa. Hasil yang diperoleh yaitu layanan bimbingan kelompok yang diterapkan kepada siswa terbukti efektif untuk meningkatkan keterampilan berkomunikasi siswa, di mana nilai rata-rata post-test lebih tinggi dari pre-test. Kemudian hasil penelitian ini juga menguatkan penelitian yang dilakukan oleh Lilianasari dan Purwanto (2016) yang menunjukkan bahwa siswa mengalami peningkatan kemampuan keterampilan komunikasi interpersonal.

\section{Kesimpulan dan Saran \\ Kesimpulan}

Berdasarkan hasil uji hipotesis dengan menggunakan Wilcoxon signed rank pada taraf signifikansi $\alpha=0,05$ diperoleh $\mathrm{P}_{\text {value }}=0,012 . \mathrm{P}_{\text {value }}<$ $\alpha(0,012<0,05)$ dengan demikian $\mathrm{H}_{0}$ ditolak. Maka dapat disimpulkan bahwa layanan bimbingan kelompok dapat meningkatkan kemampuan komunikasi interpersonal siswa kelas XI SMA Negeri 1 Maginti.

\section{Saran}

1. Bagi Sekolah. Hendaknya sekolah mendukung guru BK untuk mengaplikasikan layanan bimbingan kelompok yang terbukti efektif dalam mengatasi masalah siswa, khususnya dalam upaya meningkatkan kemampuan komunikasi interpersonal siswa.

2. Bagi Guru BK. Hasil penelitian ini sudah terbukti efektif, sehingga diharapkan dapat dijadikan bahan acuan untuk mengatasi masalah siswa, khususnya dalam meningkatkan kemampuan komunikasi interpersonal siswa melalui layanan bimbingan kelompok.

3. Bagi Siswa. Aplikasikan apa yang telah diperoleh dalam kegiatan layanan bimbingan kelompok dan dalam pelaksanaan kegiatan layanan BK selanjutnya lebih memerhatikan ketika pemimpin kelompok menyampaikan 
materi sehingga dapat lebih memahami apa yang telah disampaikan.

4. Bagi Peneliti Lebih Lanjut. Hendaknya peneliti selanjutnya khususnya yang menerapkan layanan bimbingan kelompok dalam meningkatkan kemampuan komunikasi interpersonal siswa untuk lebih memerhatikan pengorganisasian terutama ketersediaan alat/ media pendukung seperti LCD agar hasil yang diperoleh lebih baik.

\section{Daftar Pustaka}

Aw Suranto. (2011). Komunikasi Interpersonal. Yogyakarta: Graha Ilmu.

De Vito, J.A. (2016). The Interpersonal Communication Book, England: Pearson Education.

Erlangga, E. (2017). Bimbingan Kelompok Meningkatkan Keterampilan Berkomunikasi Siswa. Jurnal Ilmiah Psikologi, Vol. 4, No.1: 149-156.

Latipun. (2002). Psikologi Eksperimen. Malang: UMM Press.

(2010). Psikologi Konseling. Malang. UMM Press.

Lianasari, D. \& Purwanto, E. (2016). Model Bimbingan Kelompok Dengan Teknik Brainstorming Untuk Meningkatkan Komunikasi Interpersonal Siswa. Jurnal Bimbingan dan Konseling.

Prayitno dan Erman Amti. (2013). Dasar-Dasar Bimbingan dan Konseling. Jakarta. Rineka Cipta.

Rakhmat, Jalaluddin. 2011. Psikologi Komunikasi. Bandung: Remaja Rosdakarya.

Setyosari, Punaji. (2013). Metode Penelitian Pendidikan dan Pengembangan. Jakarta: Kencana.

Sugiyono. (2010). Metode Penelitian Pendidikan Pendekatan Kuantitatif, Kualitatif dan R\&D. Bandung: Alfabeta.

Sukardi, Dewa Ketut. 2000. Proses Bimbingan dan Konseling di Sekolah.Jakarta: Rineka Cipta.
Tohirin. (2007). Bimbingan dan Konseling di Sekolah dan Madrasah Berbasis Integrasi. Jakarta: Rajawali Press.

Wardati \& Jauhar. (2011). Implementasi Bimbingan \& Konseling Di Sekolah. Jakarta: Prestasi Pustaka.

Winkel, WS \& Sri Hastuti. (2006). Bimbingan dan Konseling di Institusi Pendidikan. Yogyakarta: Media Abadi.

Wood, J.A. (2013). Komunikasi Interpersonal. Jakarta: Salemba Humanika. 
